\title{
Employability Skills of Unaccompanied Immigrant Minors in Canary Islands
}

\author{
Estefanía Alonso-Bello®, Lidia E Santana-Vega๑ and Luis Feliciano-García® \\ Departamento de Didáctica e Investigación Educativa, Universidad de La Laguna, Spain
}

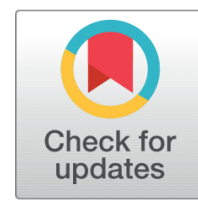

Received 2019-04-25

Revised 2019-05-06

Accepted 2019-11-27

Published 2020-01-15

Corresponding Author

Estefanía Alonso-Bello,

ealobel@gobiernodecanarias.org

Departamento de Didáctica e Investigación Educativa Facultad de Educación. Universidad de La Laguna. Avenida Trinidad s/n., Campus Central, 38200, La Laguna, Tenerife, Spain

DOI https://doi.org/10.7821/ naer.2020.1.433

Pages: 15-27

Distributed under

Creative Commons CC BY 4.0

Copyright: (c) The Author(s)

\section{ABSTRACT}

Young unaccompanied immigrants have various problems in their professional careers which lead to situations of exclusion and hinder their emancipation. The development and consolidation of employment skills is a necessary condition for the labour integration of this group. This research analyzes the employability skills of unaccompanied young immigrants who must leave the public social protection system when they reach the age of majority. A multiple case study was conducted. The cases were selected: 1) having been in residential care institutions, 2) having been in a job placement program, and 3) are 16-18 years of age. The study data were collected using qualitative and quantitative techniques. Results show that young immigrants have: a) language and socio-emotional difficulties that limit their chances of employability; b) some employability skills that facilitate labour insertion, and c) families which act as a powerful motivator for achieving their goals. We discuss the need to design individual transition plans to help young immigrants overcome their limitations, cope with the transition to adulthood and consolidate their career paths.

\section{Keywords IMMIGRANT, OCCUPATIONAL LIFE DESIGN, EDUCATION AND EMPLOYMENT, CAREER GUIDANCE, SKILLS}

\section{INTRODUCTION}

The arrival in Spain of a high number of Unaccompanied Foreign Minors (UAM) of North African and sub-Saharan origin is a complex social phenomenon because of its causes, consequences and challenges for the host society (Bravo \& Santos-González, 2017), According to the Resolution of the Council of the European Union (EU) 97/C221/03 of 26 June 1997 (Council of the European Union, 1997), UAMs are people "below the age of eighteen, who arrive on the territory of the Member States unaccompanied by an adult responsible for them whether by law or custom, and for as long as they are not effectively in the care of such a person".

The reasons that lead these minors to leave their countries are poverty, institutional vulnerability, inability to build a future, the fear of suffering the consequences of armed conflict, labour exploitation, harmful traditional practices, human rights violations and unrest

\section{OPEN ACCESS}


in their country of origin (United Nations High Commissioner for Refugges, 2016).

The Canary Islands have been one of the top five regions of Spain for the entry of UAMs. The economic, political and social circumstances of their countries of origin force these minors to migrate at increasingly young ages; these circumstances also determine the objectives of their migration projects, which could be to regularize their administrative situation, or find a job to improve their living conditions and those of their families. The UAMs accepted in Spain have the following profile: a) they are 14-17 years old, b) they are mostly men, c) they have little training, d) they have contributed to sustaining their family, e) they have work experience in informal sectors of the economy, f) they lack adequate training to access the labour market in a legally secure way, g) they do not speak Spanish, h) their families encourage them to emigrate, and i) their expectations do not conform to the administrative situation of irregular immigrants (Etxeberría, Murua, Garmedia, \& Arrieta, 2012; González \& Torrado, 2008; Iglesias, 2009). In addition, these young people: 1) suffer from a lack knowledge of bureaucratic proceedings, 2) are alone, with no family to turn to, 3) feel helpless in many situations because they do not know the language, 4) perceive that most of the resources available to them do not give them adequate emotional care, 5) find themselves in an irregular administrative situation which hinders their social and labour integration and independence (Bravo \& Santos-González, 2017). Despite the difficulties, UAMs are clear about their short and medium-term objectives which are as follows: a) to acquire job training to access the labour market, b) to set up a business as a means of selfemployment, and c) to help their families financially (Santana, Feliciano, \& Jiménez, 2016).

The recommendations contained in Regulation 604/2013 of the European Parliament, the Communication $[\operatorname{COM}(2010) 213]$ and the Communication $\{\operatorname{SWD}(2017) 129$ final\} from the Commission to the European Parliament and the Council on the protection of unaccompanied minors (2010-2014) European Commision (2010, 2017); European Parliament (2013) , call on EU Member States (a) to provide protection measures for UAMs, (b) to ensure the regularization of their administrative status and (c) to provide them with opportunities to complete their education, have access to suitable jobs and integrate into the society in which they live. In Spain, these recommendations are incorporated in part by Act No. 26/2015 of 28 July 2005 amending the system for the protection of children and adolescents.

The arrival of UAMs in the Canaries has had a great impact on the system of residential care as a protective measure, and has required the introduction of training programs to: 1) facilitate the learning of the language and culture of Spain, 2) inform the UAMs about the functioning of the administration and their legal rights, and 3) improve their employability skills.

Social and employment integration processes are complex and idiosyncratic (Arnau \& Gilligan, 2015; Santana, 2013, 2015). The transition to adulthood for UAMs has many obstacles. How they address this transition will determine whether they find themselves in a position of social exclusion or not (Medrano, Alonso, Díez, \& Ferrandis, 2009; Parrilla, Gallego, \& Moriña, 2010). If UAMs are not properly integrated into their school environment, their work or with their hosts, they will find themselves in marginal situations leading to feel- 
ings of frustration and insecurity (Reillo, 2013). Hilles, Moss, Wright, and Dallos (2013) point out that "in seeking the best way to support those both within and leaving care, it is important to understand the pathways to successes as well as those that lead to difficulties" (p. 2060). Young immigrants value their training as a vehicle for immediate access to employment (Rodríguez, Juanas, \& González, 2016). Socio-labour guidance programmes are necessary so that these young people, like other young people of their age, a) feel supported, b) strengthen their social skills and their relationship networks, and c) can face their career development in a flexible and thoughtful way (Dixon, 2016; Gilligan \& Sabatés, 2017; Pérez \& Melendro, 2016; Sala, Villalba, Jariot, \& Arnau, 2013; Santana, Feliciano, \& Cruz, 2010; Sulimani-Aidan, 2014). The aims of the present study are as follows:

- To analyze how certain life experiences can influence the labour integration and independence of young immigrants who leave the protection system.

- To analyze the needs of the UAM during their transition to adulthood.

Based on theoretical approaches, the study's hypotheses are as follows: 1) The life projects of UAMs are marked by the economic conditions of their families; 2) UAMs' families act as a powerful support mechanism for achieving their goals; 3) UAMs consider training a vehicle for finding employment; 4) UAMs with employability skills increase their employability possibilities; 5) UAMs with a restricted social network have greater problems finding employment and becoming autonomous. The dimensions of information analyzed in the study are: a) UAMs' family and personal situation; b) Knowledge and work experience; c) Training; d) Social network; e) Labour insertion project; h) Life design.

\section{METHODOLOGY}

A multiple-case study was planned to carry out the research, since the evidence obtained from this type of design is more convincing by allowing the partial responses obtained in each of the cases analyzed to be contrasted. A qualitative research methodology was chosen, whose inductive and emergent design allows: a) highlighting throughout the study of new situations related to the analyzed topic, which may imply changes to the research questions; 2) application of new data collection techniques at different times in the process; 3 ) conceptual elaboration of the data in an original way during the research process (Mendizábal, 2009). The multiple-case study is based on: 1) emphasis on long-term observations, based more on descriptive reports than on pre-established categories; 2) interest in describing observed behaviour, within the framework of the surrounding facts; 3 ) concern for the participants' perspectives on the facts; that is, how they construct their social reality; 4) the specifics that differentiate a case from other similar ones, so that a vivid and unique image of the situation is offered (Cebreiro \& Fernández, 2004). The research was conducted over three years, during the implementation of a work insertion project called "We climbed the stairs together: promoting youth independence" developed by the Kanaria Association of Childhood and funded by the Department of Social Welfare, Youth and Housing of the Government of the Canary Islands. 


\subsection{Participants}

The process of social integration and independence of four sub-Saharan UAMs was analyzed over a period of three years. Case selection was theoretical and intentional, identifying typical cases. The selected cases met the following criteria: a) they belonged to the group of young people at risk of social exclusion, b) they were looked after under a system of state protection, c) they had participated for at least six months in a work integration project, d) they were unaccompanied minors, e) they were aged 16-18. Additionally, residential care center tutors and entrepreneurs who supervised the work placements participated in this study.

A double filter was applied for the selection of the cases: a) a first information session for young people interested in participating in this research work; b) later on, to ensure that the criteria were met, an individual session was held to agree the key points of the process with each young person selected and to ensure informed consent. The four cases selected resembled each other and, in a way, they were also unique. We were interested in what they had in common as well as their singularities when addressing employment integration and independence processes. Common factors in the four cases were having been declared distressed minors on arrival in Spain and being received for two or more years by the protection system. The four UAMs participated in the Insertion Project and, after reaching the age of majority, they continued to live in supervised flats.

\subsection{Techniques and instruments}

Different data collection techniques were used to obtain information on the dimensions under analysis. The interviews with the minors and their tutors provide information on various personal circumstances and on their pre-employment and employment skills. The individual transition plans provide information on the initial situation of the minors and their goals. The worksheets are exercises performed on various topics within the labour environment relevant to each minor. The field diaries provide information on the sessions which the UAMs participated in. The control registers provide information regarding the attendance of the minors, punctuality, etc. The work placement questionnaires, completed by the employers to report on the placements, provide information on the UAMs' adjustment to the job, weaknesses and potential. The dropout reports provide information on the UAMs' evolution during their participation in the project, the objectives achieved and reasons for their dropout.

\subsection{Procedure}

The research work was performed in two phases. The first described the processes of social and employment integration and independence through direct and individual work with the UAMs and culminated in the drafting of the reports on the four cases. The aim of the second phase was to conduct a comparative study analyzing the common and differential aspects of the social and employment integration and independence processes of the UAMs.

The analysis of information from the interviews, individual transition plans, worksheets, field diaries and placement and dropout reports was simultaneous to the data collection 
and was carried out by qualitative content analysis. Initially, the system of codes and categories was generated deductively from the dimensions of the information analysed, and then inductively during the analysis of the information obtained. This system consists of six dimensions of information, twelve categories and thirty-seven codes (Table 1).

Atlas-Ti software was used in the analysis of the information. The following two processes were used to ensure the credibility of the results: a) a large collection of data was taken, and $b$ ) the sources and techniques were triangulated.

Table 1 Dimensions, Categories and Codes of analysis

\begin{tabular}{|c|c|c|}
\hline Dimensions & Categories & Codes \\
\hline \multirow[t]{3}{*}{ Family and Personal Situation } & Family & $\begin{array}{l}\text { Family Structure (F.E.) } \\
\text { Family Relationship (F.R.) }\end{array}$ \\
\hline & Reception Centres & $\begin{array}{l}\text { Distressed Minor Declaration (D.M.D.) } \\
\text { Number of Centres (N.C) } \\
\text { Time Spent at the Centre (T.S.C) } \\
\text { Relatives in Centre (R.C.) }\end{array}$ \\
\hline & Personal Situacion & $\begin{array}{l}\text { Basic Needs (B.N) } \\
\text { Emancipation (EM.) }\end{array}$ \\
\hline \multirow[t]{2}{*}{ Knowledge and Work Experiences } & Pre-employment Knowledge & $\begin{array}{l}\text { Employment Search strategies (E.S.E) } \\
\text { Autonomy in Search of Employmet (A.S.E.) }\end{array}$ \\
\hline & Career Path & $\begin{array}{l}\text { Employments (Emp.) } \\
\text { Woprk Contract (W.C.) } \\
\text { Employability Skills (E.S.) } \\
\text { Difficulties Accessing employment (D.A.E.) }\end{array}$ \\
\hline \multirow[t]{2}{*}{ Training } & Studies & $\begin{array}{l}\text { Degree Level (D.L.) } \\
\text { Other Studies (O.Est.Est.C.) } \\
\text { Academic Achievement (Ac.Ach.) }\end{array}$ \\
\hline & Continuity/Dropping out of School & $\begin{array}{l}\text { School Dropout (S.Dr.) } \\
\text { Training Expectations (T.Ex.) }\end{array}$ \\
\hline \multirow[t]{2}{*}{ Social Network } & Social Network Structure & $\begin{array}{l}\text { Social Network Members (S.N.M.) } \\
\text { Social Network Valuation (S.N.V.) }\end{array}$ \\
\hline & Leisure Time & $\begin{array}{l}\text { Leisure Activities (L.Act.) } \\
\text { Leisure Companions (L.Comp.) }\end{array}$ \\
\hline \multirow[t]{2}{*}{ Labor Insertion Project } & Reasons for Participation in the Project & $\begin{array}{l}\text { Reasons for Participation (R.Part.) } \\
\text { Professional Expectations (Pro.Ex.) }\end{array}$ \\
\hline & Valuation of the Project & $\begin{array}{l}\text { Knowledge (Kn.Pro) } \\
\text { Services (Serv.Pro) } \\
\text { Practices (Pract.Pro.) } \\
\text { Tutors (Tut.Pro.) } \\
\text { Contribution to Labour Insertion (Contr.Pro.) }\end{array}$ \\
\hline \multirow[t]{2}{*}{ Life Design } & Aims & $\begin{array}{l}\text { Academic Aims (Ac.A.) } \\
\text { Professional Aims s (Prf.A.) } \\
\text { Family Aims (Fam.A.) } \\
\text { Economics Aims s (Ec.A.) } \\
\text { Social Aims (Soc.A.) }\end{array}$ \\
\hline & Expectations & $\begin{array}{l}\text { Labor Expectations (Lab. Ex.) } \\
\text { Professional Interests (Prof.Int.) }\end{array}$ \\
\hline
\end{tabular}




\section{RESULTS}

\subsection{The UAMs' life projects are marked by the economic conditions of their families}

The unaccompanied foreign minors' life projects are linked to the family circumstances that have forced them to leave their country. Their main objective is to improve their living conditions and those of their families: "My life is conditioned by the need to work in order to live safely, legally" (Abdou); "The most important thing for me is to work on anything to help my family" (Ousmane); "My objective is to look for a job, whatever it is, to be hired and to keep my job" (Modou).

The need to find work leads them to opt for any type of employment. This circumstance implies that they have poorly defined employment interests; in their opinion any job is good as long as it helps them financially: "I would like to work on something where I can earn money, without much training, such as picking up and selling garbage" (Abdou); "I'm not sure what I'd like to work on, I wouldn't mind working as a waiter, bricklayer, ..." (Moussa); "I don't know what I would like to do, maybe work as a welder or in hotels; I don't care about the working conditions or the number of hours I work" (Ousmane); "I don't know what I want to do, what I want to do in the future" (Modou).

The young immigrants consider that training for employment is a way of entering the world of work, with its potential for emancipation. However, the precariousness of their situation and the need to immediately strengthen the economy of their families means that, initially, training is not a priority objective for them: "If I could study I would like to learn something, history, English..., but this is something long-term" (Ousmane).

\subsection{The UAMs' families act as a powerful support mechanism for achieving their goals}

The four cases analyzed have a history of immigration marked by the lack of economic resources in their families. In addition, there are situations of violence that, in some cases, make them fear for their future and that of their families: "My father was a journalist and was murdered. My mother encouraged me and my brother to leave the country because she thought the same thing was going to happen to us. (Modou).

The young immigrants are aware of their precarious situation and their obligation to strengthen the weak financial position of their families. Their intention when migrating is to arrive in a country where they have the possibility to start working as soon as possible, send money to their parents, raise enough capital to start their own business and, in this way, develop their life projects. The reality that awaits them is quite different. In accordance with Organic Law 8/2015 of 22 July (Boletín Oficial del Estado, 2015) on the modification of the system of protection for children and adolescents, Abdou, Moussa, Ousmane and Modou are declared distressed minors and sent to protection centres for 1 or 3 years, until they reach 18 years of age.

The problem arises when they leave the protection system; some may go to a supervised flat, but do not have a residence or work permit, so their future is uncertain: "My resi- 
dence permit has already expired" (Ousmane); "I don't have a work permit"; "Although I have a passport, my residence card expires three months after my 18th birthday" (Moussa). Not having administrative documentation in order means not being hired, or entering the dynamics of the black market, which frustrates the expectations with which young immigrants arrived in our country: "I despair of not having a job and that hurts me. I once worked illegally because they promised me a contract that they never signed" (Moussa).

The UAMs do not have close family support to deal with the problems arising from their situation. Their families keep in touch with their children, via the internet or mobile phone, and constitute their main support so that they persevere in their objectives of entering the labor market and helping them financially.

\subsection{The UAMs consider training a vehicle for finding employment}

The UAMs completed primary education in their countries; some even began secondary education and spoke two languages. Although it was not necessary for them to continue training, their incorporation into the labor market insertion project implied a rethinking of this need:

(The project) has made me see the importance of job training to improve my chances of getting a job... Now I am more interested in taking courses and I want to study more.

Abdou

The UAMs cannot access the labour market, since they are minors and do not have regularized documentation; for this reason, they see in the training courses offered in the project an option that opens the door to the labour market. This rethinking of the value of vocational training leads Abdou, Mousa, Modou and Ousmane to enroll in different courses and workshops: food handler, painting and maintenance of buildings, Spanish language, computer user level, basic English, masonry, maintenance of computer systems, nutrition, installation of electronic and telecommunications systems in buildings, etc.

The labour insertion project implies for young inmigrants, therefore, a redefinition in the objectives of their life design. They continue to show their concern for access to the labour market, but they value the implementation of labour training courses, as they facilitate such access:

He shows that he is fully involved in his training process, he is aware of the need for training in order to improve his job search possibilities.

Abdou's Tutor

He is fully aware of the need to be trained in order to improve his possibilities in the search for employment (...) sometimes he is not very participative and absent in class (...), he comments that this is a reflection of his state of mind.

Moussa's Tutor 


\subsection{The UAMs with employability skills increase their employability possibilities}

The young immigrants have had work experience in their countries of origin to help meet the economic needs of their families; such work experience required low job skills: farmer, shopkeeper, furniture repairer and seller, animal caretaker, vehicle cleaner, rancher, mobile phone salesman. They are generally lacking in the use of job search strategies, except for Abdou: "I have looked for a job and I know what a curriculum vitae is, how to deliver it and how to look for an offer in a newspaper and on the Internet".

Alongside these shortcomings, the tutors point out others relating to language and the social skills necessary for job performance:

You have to work with him on his language skills, especially the vocabulary specific to job search, learn to ask for help and develop conflict resolution tools.

Moussa's Tutor

It is necessary to improve active listening, empathy, and values of tolerance, dialogue and respect for the female figure, as well as language" (Modou's Tutor). Faced with these shortcomings, the tutors emphasize qualities in young people that encourage work performance: punctuality, respect for peers, and responsibility in carrying out tasks

The involvement of young people in the insertion project implies a change in the use of some job search strategies, as well as in the acquisition/consolidation of social skills:

He has been progressively carrying out actions such as making presentation letters, making phone calls or sending CVs via email.

Abdou's Tutor

It highlights his high level of skills such as: at-tendance, punctuality, initiative, ease of learning, group work...

Ousmane's Tutor

Sometimes the situation of extreme uncertainty experienced by the UAMs does not stimulate their learning or the improvement of their strategies and skills for seeking and keeping a job:

He is not aware of the effort involved in looking for a job, getting it and keeping it. He appears to be afraid when facing these situations, chooses to avoid them or ask someone to accompany him (...), he gets nervous, says he wants to go back to his mother.

Modou's Tutor 


\subsection{The UAMs with a restricted social network have greater problems finding employment and becoming autonomous}

Upon arrival, the UAMs live first in immediate reception centres, and then in protection system centres. In the centres, they share their stay with other young immigrants. In the absence of close family relations, the UAMs create a social network with other young immigrants from the centres; through this network, the young people support each other when faced with the problems of daily life.

The UAMs' social skills enable them to relate to others and expand the network to include non-immigrant youths: "I tend to get along well with people, I have friends in the centre, and when I take part in activities I get to know other people" (Abdou); "I interact with boys from the centre (...), although my Spanish is not good, I can interact without difficulty with other boys and girls" (Moussa). As a result of their participation in the activities of the labour insertion project and in leisure activities, the UAMs' social network increases progressively; a network that offers them opportunities for social and labour integration: "Participating in workshops and leisure activities has allowed me to know and have friends of many nationalities, now I know many people, I feel integrated with them" (Abdou); "In the courses and in the practices I relate to other boys and girls (...) I have met a girl with whom I share my free time" (Moussa); "At the beginning I only had friends in the centre, now I know many people (...) by participating in training activities, internships in the enterprise and the football team" (Modou).

From a relatively closed network of relationships, the UAMs move to a much wider and gradually expanding network. Participation in the labour insertion project and leisure activities increases the opportunities to establish relationships beyond the context of the centres where they live. It also gives the UAMs a new perspective on their situation in the host social context, and is a way for future employees and employers to get to know each other in order for the UAMs to secure jobs.

The presence of a strong social support network is key to increasing the chances of emerging from social exclusion. During the project, the UAMs carried out activities in new scenarios that increased their social support network and their possibilities of socio-labour transition.

\section{DISCUSSION AND CONCLUSION}

The cases described here show how the needs of the UAMs determine the success or failure of their plans for autonomy. Some of the difficulties identified confirm the view of (Reillo, 2013): young people have felt helpless because they do not have language skills and because they do not know cultural keys in the host society. The following are some considerations regarding the study hypotheses:

- Life design. The UAMs' priority objectives are to get employment to support themselves and help their families and, if possible, to keep on studying. They should be helped to review their goals, and to have a clear idea about what their aims are in the various areas of their life project, which would motivate them to make an effort to 
reach these goals (Santana, Alonso, \& Feliciano, 2018). Guidance programs aimed at UAMs should be based on the psychological theory of vocational behaviour that comes from an epistemological approach called "life design"; this constructionist approach to career development emphasizes flexibility, employability, commitment, emotional intelligence and life-long learning (Savickas et al., 2009).

- Family emotional support. Families of these young people act as a motivating force for achieving their goals. Despite the geographical distance, the families offer emotional support to persevere with their life plan. Training is usually highly valued by the UAMs' families, although their socioeconomic circumstances affect decisions on whether to enter the labour market immediately (Santana et al., 2018). This decision is endorsed by the family; despite the value they attach to training, the UAMs are aware of their precarious situation and the need to strengthen a weak household economy. Insertion projects have to take advantage of family support given to the UAMs so they can go on with their life projects.

- Training. The priority of a UAM is to get a job and they, therefore, place a lot of importance on training in the workplace, which is given by companies in the placement programs. Our results agree with those of Rodríguez et al. (2016): young immigrants value their training as a vehicle for immediate access to employment or as a way to increase their chances of social and employment insertion. Integration projects need to contemplate occupational training, provided it meets the demands of the labour market, as a fundamental pillar in the social and work insertion of the UAMs.

- Employability skills. The UAMs had employability skills that favoured their chances of getting work. The education received in their families may have given them these skills, and these were consolidated during their work experience. Entrepreneurs prefer to offer long-term contracts to UAMs with proven employability skills along with the experience and training acquired in the work placement. The UAMs who found employment had no specific training in the job, however the business community praised their attitudes and proven work skills. Our results agree with those of the Sala et al. (2013): the UAMs who successfully enter the labour market are more adaptable and have better social skills than those who fail. Insertion projects should help these young people to improve their willingness to work, motivation, self-confidence and other employability skills which need improvement during their working life (Dixon, 2016; Gilligan \& Sabatés, 2017).

- Social support network. It is necessary to support the network of relationships of young people leaving care (Hilles et al., 2013). The UAMs have a restricted social network in which there are only professionals and young people in their reception centres; during the project, they participate in activities in new situations where they could expand their social network and enhance their chances of social and work transition. Projects aimed at the integration and independence of UAMs need to transversally work on extending their social support network. Emotional support and development of recreational, sports and training activities need to be considered in such projects (Newbiggin \& Thomas, 2011; Pérez \& Melendro, 2016; Sulimani- 


\section{Aidan, 2014).}

In short, the UAMs lack job-seeking strategies, which limits their possibilities in the labour market. In addition, family economic reasons have led them to leave their country. The priority of finding work as soon as possible in order to respond to the needs of their families is a constraint on the development of their career paths.

Social and educational projects should provide UAMs with consolidated support networks, employability skills, reflection on the value of education, construction of their life projects, and employment insertion through placement programs. These projects should take into account the culture, the socioeconomic context of the minors and their maturity to give an appropriate educational response to the reality of UAMs (Iglesias, 2009).

\section{STUDY LIMITATIONS AND FUTURE RESEARCH LINES}

The study has several limitations. It is necessary to analyze a larger number of cases to get a better idea of the life trajectories and needs of UAMs. The fact that the immigrant minors are involved in a job placement program allowed us to analyze how this experience modulates their paths. However, the interest of young people in voluntarily participating in the program does not show all young people at risk of exclusion; this reduces the scope of our findings. The study was conducted only with males; this circumstance leads to the question of whether the findings with immigrant women may be similar. It is necessary to give greater attention to female UAMs; girls should be helped to overcome any obstacles they may encounter during the integration process due to the mere fact of being female, besides being alone and being migrants (Acorinti, 2015).

The study opens up new avenues for research on the transition and independence processes of UAMs, and the factors that should be involved in interventions to help them leave a path of exclusion. It is worth considering the following issues for further research: What are the differences and similarities of young immigrant men and women at risk of exclusion regarding their needs and life paths? How do UAMs who do not join the employment insertion programs face the processes of transition to the working world? How should these young people be worked with on their life design and on their emotional intelligence? Understanding the processes by which UAMs leave or do not leave their situations of exclusion and providing intervention strategies to counter such situations is a promising field for future research.

\section{REFERENCES}

Acorinti, M. (2015). Unaccompanied foreign minors in Italy. Procedures and practices. Review of History and Political Science, 3(1), 60-72. https://doi.org/10.15640/rhps.v3n1a6

Arnau, L., \& Gilligan, R. (2015). What helps young care leavers to enter the world of work? Possible lessons learned from an exploratory study in Ireland and Catalonia. Children and Youth Service Review, 53, 185-191. https://doi.org/10.1016/j.childyouth.2015.03.027

Boletín Oficial del Estado. (2015). Ley Orgánica 8/2015, de 22 de julio, de modificación del sistema de protección a la infancia y a la adolescencia. Retrieved from https://www.boe.es/boe/dias/ 


\section{5/07/23/pdfs/BOE-A-2015-8222.pdf}

Bravo, A., \& Santos-González, I. (2017). Menores extranjeros no acompañados en España. Necesidades y modelo de intervención. Psychosocial Intervention, 26(1), 55-62. https://doi.org/ 10.1016/j.psi.2015.12.001

Cebreiro, B., \& Fernández, M. C. (2004). Estudio de casos. In F. Salvador, J. L. Rodríguez, \& A. Bolivar (Eds.), Diccionario enciclopédico de didáctica. Málaga: Aljibe. Estudio de casos.

Council of the European Union . (1997). Council Resolution 97/C 221/03 of 26 June 1997 on unaccompanied minors who are nationals of third countries. Retrieved from http://eur-lex.europa.eu/ legal-con-tent/ES/TXT/PDF/?uri=CELEX:31997Y0719(02)\&from=EN

Dixon, J. (2016). Opportunities and challenges: supporting journeys into education and employment for young people leaving care in England. Revista Española de Pedagogía, 263, 13-29.

Etxeberría, F., Murua, H., Garmedia, J., \& Arrieta, E. (2012). Menores Inmigrantes no acompañados en Euskadi y Aquitania. Elaboración y puesta en marcha de un programa de formación para educadores y responsables. Revista de Educación Social, 15, 1-28. Retrieved from http:// www.eduso.net/res/pdf/15/mena_res_15.pdf

European Commision. (2010). COM(2010)213] from the Commission to the European Parliament and the Council on the protection of unaccompanied minors. Retrieved from https://eur-lex .europa.eu/LexUriServ/LexUriServ.do?uri=COM:2010:0213:FIN:EN:PDF

European Commision. (2017). Communication $\{S W D(2017) 129$ final\} from the Commission to the European Parliament and the Council on the protection of children in migration. Retrieved from https://eur-lex.europa.eu/legal-con-tent/EN/TXT/PDF/?uri=CELEX: 52017DC0211\&from $=\mathrm{EN}$

European Parliament. (2013). Regulation (EU) No 604/2013 of the European Parliament and of the Council of 26 June 2013 establishing the criteria and mechanisms for determining the Member State responsible for examining an application for international protection lodged in one of the Member States by a third-country national or a stateless person. Retrieved from Retrievedfromhttps://eur-lex.europa.eu/legal-content/en/ALL/?uri=celex\%3A32013R0604

Gilligan, R., \& Sabatés, L. (2017). The role of carers in supporting the progress of care leavers in the world of work. Child and Family Social Work, 22(2), 792-800. https://doi.org/10.1111/ cfs. 12297

González, I., \& Torrado, E. (2008). Frente a frente. Proyectos educativos y proyectos migratorios de menores extranjeros no acompañados en Canarias. Revista Qurriculum, 21, 103-135.

Hilles, D., Moss, D., Wright, J., \& Dallos, R. (2013). Young people's experience of social support during the process of leaving care: A review of the literature. Children and Youth Service Review, 35, 2059-2071. https://doi.org/10.1016/j.childyouth.2013.10.008

Iglesias, J. (2009). Retrieved from http://www.casafrica.es/casafrica/Agenda/2009/11_MENA Informe.PDF

Medrano, C. V. D., Alonso, C., Díez, M., \& Ferrandis, A. (2009). Educación y protección de menores en riesgo. Barcelona: Grao.

Mendizábal, N. (2009). Los componentes del diseño flexible de la investigación cualitativa. En Vasilachis, I., Estrategias de investigación cualitativa. Barcelona: Gedisa.

Newbiggin, K., \& Thomas, M. (2011). Good practice in social care for refugee and asylum- seeking children. Child Abuse Review, 20, 374-390. https://doi.org/10.1002/car.1178

Parrilla, A., Gallego, C., \& Moriña, A. (2010). El complicado tránsito a la vida activa de jóvenes en riesgo de exclusión: una perspectiva biográfica. Revista de Educación, 351, 211-233.

Pérez, G., \& Melendro, M. (2016). Ocio, formación y empleo de los jóvenes en dificultad social. Revista Española de Pedagogía, 263, 5-11.

Reillo, P. L. (2013). Young African migrants reinventing their lives in the Canary Islands. Shima. 
The International Journal of Research into Island Culture, 7(2), 39-54.

Rodríguez, A., Juanas, A. D., \& González, A. (2016). Atribuciones de los jóvenes en situación de vulnerabilidad social sobre los beneficios del estudio y la inserción laboral. Revista Española de Pedagogía, 263, 109-126.

Sala, J., Villalba, A., Jariot, M., \& Arnau, L. (2013). Socialization process and social support networks of out-of-care youngsters. Children and Youth Services Review, 34(5), 1015-1023. https:// doi.org/10.1016/j.childyouth.2012.02.002

Santana, L. E. (2013). Orientación profesional. Madrid: Síntesis.

Santana, L. E. (2015). Orientación educativa e intervención psicopedagógica (4aed.). Madrid: Pirámide.

Santana, L. E., Alonso, E., \& Feliciano, L. (2018). Trayectorias laborales y competencias de empleabilidad de jóvenes nacionales e inmigrantes en riesgo de exclusión social. Revista Complutense de Educación, 29(2), 355-369. https://doi.org/10.5209/RCED.52444

Santana, L. E., Feliciano, L., \& Cruz, A. (2010). El Programa de Orientación Educativa y Sociolaboral: un instrumento para facilitar la toma de decisiones en educación secundaria. Revista de Educación, 351, 73-105.

Santana, L. E., Feliciano, L., \& Jiménez, A. B. (2016). Perceived family support and the life design of immigrant pupils in secondary education. Revista de Educación, 372, 32-58. https://doi.org/ 10.4438/1988-592X-RE-2015-372-314

Savickas, M. L., Nota, L., Rossier, J., Dauwalder, J. P., Duarte, M. E., \& Guichard, J. (2009). Life designing: A paradigm for career construction in the 21st century. Journal of Vocational Behavior, 75, 239-250. https://doi.org/10.1016/j.jvb.2009.04.004

Sulimani-Aidan, Y. (2014). Care leavers' challenges in transition to independent living. Children and Youth Services Review, 46, 38-46. https://doi.org/10.1016/j.childyouth.2014.07.022

United Nations High Commissioner for Refugges. (2016). Los menores no acompañados y la protección del asilo. Retrieved from http://www.acnur.org/t3/a-quien-ayuda/ninos/los-menores -no-acompanados-y-la-proteccion-del-asilo/ 